\title{
Foraging Ecology of Bison in Aspen Boreal Habitats
}

\section{R.J. HUDSON AND S. FRANK}

\section{Abstract}

Studies on several wild and domestic ungulates suggest that large grazers attain higher maximum forage intake rates but require relatively higher forage biomass to do so. In this study, forage intake rates and feeding times of North America's largest wild grazer, the bison (Bison bison), were related to forage biomass during summer and autumn in aspen boreal forest habitats. Irrespective of season, maximum feeding rates of $68 \mathrm{~g} / \mathrm{min}$ declined by $50 \%$ as forage biomass was reduced to $780 \mathrm{~kg} / \mathrm{ha}$. This reduction was due primarily to smaller bite sizes. However, bison compensated by increasing cropping bite rates to more than $60 \mathrm{bites} / \mathrm{min}$ on heavily grazed swards. Grazing times increased from $9 \mathrm{~h} /$ day in summer to $11 \mathrm{~b} / \mathrm{day}$ in autumn, offsetting slight decreases in average foraging eficiency. During summer, a greater proportion of grazing occurred at night. Upland meadows were preferred habitats for grazing despite relatively low pasture biomass and potential dry matter intake rates.

\section{Key Words:ruminant nutrition, forage intake, forest range}

Bison once occupied a vast geographical range and wide variety of habitats. Historically, the main Canadian populations were distributed south of the North Saskatchewan River where they offered a major source of meat and hides for native people, fur traders, and later settlers (Roe 1970). Today, most bison in Canada are privately owned, although approximately 8,000 still exist in parks and reserves. Despite the historical importance of bison and their emerging role as a farm animal, their nutritional ecology remains poorly understood (reviewed by Reynolds et al. 1982). Because almost all populations are confined and highly fragmented, we may never know exactly how they used the forage resources of prairies and parklands (Moodie and Kay 1976, Mor-

\footnotetext{
Authors are professor and research technician, Department of Animal Science, University of Alberta, Edmonton, Canada T6G 2P5.

Research was supported by the Natural Sciences and Engineering Research Council of Canada.

Manuscript accepted 7 July 1986.
}

gan 1980). However, by examining their response to forage biomass, structure, and quality, we may better understand their original trophic niche.

As North America's largest herbivore, bison offer several insights into potential constraints of body size on nutritional ecology. It is widely accepted that larger herbivores are able to subsist on low quality forages, a fact borne out by comparative studies of digestive efficiency (Richmond et al. 1977, Hawley et al. 1981). Large animals also possess considerable thermal inertia and can thrive in extremely cold environments (Christopherson et al. 1978, 1979). However, large body size has its disadvantages as well; although weight-specific energy requirements of large animals are low (Hudson and Christopherson 1985), bison nevertheless require substantially more forage in absolute terms than do smaller herbivores. These high levels of forage intake could be achieved by: foraging longer, cropping forage faster, taking larger bites, or selecting habitats which allow higher consumption rates. This study was conducted to evaluate these foraging alternatives. In particular, we wanted to test the hypothesis that large grazers such as bison require higher forage biomass to meet their greater daily forage requirements.

\section{Study Area and Animals}

Observations were made at the Ministik Field Station, located in the Beaver Hills $50 \mathrm{~km}$ south east of Edmonton, Alberta. The area falls within the boreal mixed-wood forest zone (Rowe 1972) but a history of burning and grazing have left few coniferous elements. Until the middle of the last century, the area supported sizable populations of bison particularly during winter.

Deciduous forests, grasslands, and wet meadows were all about equally represented in the study area. The dominant forest overstory was balsam poplar (Populus balsamifera) on wetter sites and trembling aspen (Populus tremuloides) elsewhere. Upland meadows were comprised of Poa pratensis and Bromus inermis. Low- 
land meadows supported Poa, Calamagrostis, and Juncus. The wettest sites, ringed by willow (Salix) fens, supported vigorous stands of sedge (Carex aquatilis, C. rostrata).

The station has been heavily stocked since 1977 with wapiti (Cervus elaphus), moose (Alces alces), and bison. At the time of the study, the bison herd consisted of 1 adult bull, 3 subadult bulls, 7 cows, 4 yearlings (including 3 females), and 1 calf. They were thoroughly habituated to human presence and could be observed without disturbance from within $20 \mathrm{~m}$.

\section{Methods}

We evaluated activity budgets, habitat selection, and foraging behavior of free-ranging bison during June-July when pastures were green and in September-October when vegetation had cured. The 2 periods were separated by the peak of the rut during August. This provided an opportunity to explore influences of forage biomass and quality on feeding behavior.

\section{Activities and Habitat Selection}

Feeding times and habitat selection of herd members were recorded during one 24-hr scan and one $12 \mathrm{~h}(0600-1800 \mathrm{~h})$ scan in each season. Observation dates were selected to be representative of seasonal meterological conditions. The July scans were conducted when maximum temperatures were $21-25^{\circ} \mathrm{C}$. Maximum temperatures during October scans were $10-13^{\circ} \mathrm{C}$.

Activity states (feeding/not feeding) and habitats occupied (upland meadows, lowland meadows, sedge meadows, and aspen/poplar forests) were recorded every $10 \mathrm{~min}$. Because identification of individual animals was sometimes uncertain, particularly at night, hourly tallies had to be made on the basis of sex/age classes. This obviated statistical analysis of differences between seasons.

\section{Foraging Bahavior}

We recorded foraging behavior according to a protocol used previously to study wapiti (Hudson and Nietfeld 1985) and moose (Renecker and Hudson 1986) in the same area. While engaged in relatively uninterrupted foraging bouts, selected individuals were observed for 1-5 min intervals during which cropping bite rates were recorded with an electronic event-recorder. We ended measurements when individuals interrupted feeding, e.g., to walk to a different habitat, groom, or interact with other animals. We immediately collected 20 simulated bites to represent the quantities selected by the focal animal. This procedure was necessarily subjective, but on the upland swards used to derive functional relationships, little selectivity was apparent; estimating bite sizes was mainly a matter of estimating the depth within the sward that the animal grazed. Bite sizes estimated from oven-dried weights $\left(60^{\circ} \mathrm{C}\right.$ to constant weight) were paired with dry forage biomass determined by plucking a single $0.25 \mathrm{~m}^{2}$ plot situated within several meters of the location grazed. Consumption rates $(\mathrm{g} / \mathrm{min})$ were calculated as the product of bite rate $(\mathrm{g} / \mathrm{min})$ and bite size $(\mathrm{g} / \mathrm{bite})$ for a total of 37 observations.

Data from subadult bulls, cows, and yearlings were pooled; the single senior bull and calf were excluded from analysis. Because it was difficult to determine the proportion of aboveground biomass available to bison, data for sedge meadow habitats were not used. We estimated maximum foraging rates $(A)$ and vegetation biomass at which foraging rates were reduced to $50 \%$ of the maximum (critical biomass, $\mathrm{B}^{50}$ ) using asymptotic regression (Dixon 1981). The fitted curve was one of the form, $R=\mathrm{A} \times \mathrm{B} /\left(\mathrm{B}^{50}+\mathrm{B}\right)$, where $\mathrm{B}$ is vegetation biomass. This equation is equivalent to the more familiar form, $R=\mathrm{A}\left(1-\mathrm{e}^{-\mathrm{kB}}\right)$, where $k=\ln (2) / \mathrm{B}^{50}$. Interrelationships of bite sizes to forage biomass and biting rates to bite sizes were explored by regression analysis using logarithmic transformations.

\section{Results}

\section{Activity Budgets and Habitat Selection}

On summer pastures, bison grazed $8.7 \mathrm{~h} / \mathrm{d}$ but this increased to
Table 1. Proportion of time spent graxing (\%).

\begin{tabular}{lccccc}
\hline \hline & & \multicolumn{4}{c}{ Date } \\
\cline { 3 - 6 } & Scan & Jul 20 & Jul 28 & Oct 20 & Oct 22 \\
\hline $\begin{array}{l}\text { Adult cows } \\
(n=7)\end{array}$ & $24 \mathrm{~h}$ & 38.8 & - & 45.1 & - \\
Subadult bulls & $12 \mathrm{~h}$ & 46.6 & 51.9 & 67.7 & 53.6 \\
$(n=3)$ & $24 \mathrm{~h}$ & 35.4 & - & 43.1 & - \\
$\begin{array}{l}\text { Yearlings } \\
(n=4)\end{array}$ & $12 \mathrm{~h}$ & 42.2 & 47.4 & 63.2 & 55.6 \\
& $24 \mathrm{~h}$ & 34.9 & - & 45.8 & - \\
& $12 \mathrm{~h}$ & 40.6 & 46.4 & 69.1 & 55.6 \\
\hline
\end{tabular}

IProportion of time spent grazing was calculated on the basis of 12 and 24 hours. Scans on $28 \mathrm{Jul}$ and $22 \mathrm{Oct}$ were conducted for only $12 \mathrm{~h}(0600-1800 \mathrm{~h})$.

$10.7 \mathrm{~h} /$ day on cured autumn pastures (Table 1). The proportion of time pent grazing between 0600 and $1800 \mathrm{~h}$ increased from $46 \%$ in July to $61 \%$ in October. Subadult bulls, adult cows, and yearlings behaved similarly. Foraging was organized into 4-5 main bouts in both seasons but during July there was less synchrony among sex/age classes (Fig. 1).

Although activities were not always synchronized, bison tended to remain in one herd, particularly in autumn. Habitats used for grazing ranked similarly in both summer and autumn (Table 2).

Table 2. Proportion of grazing time' spent by bison in each habltat in relation to fornge biomass.

\begin{tabular}{|c|c|c|c|c|}
\hline & \multicolumn{2}{|c|}{ July } & \multicolumn{2}{|c|}{ October } \\
\hline & 20 & 28 & 20 & 22 \\
\hline $\begin{array}{l}\text { Sedge meadow } \\
24 \mathrm{~h} \\
12 \mathrm{~h}\end{array}$ & $\begin{array}{l}4335 \pm 714 \\
28 \% \\
34 \%\end{array}$ & $\begin{array}{l}\mathrm{kg} / \mathrm{ha} \\
\frac{1}{17} \%\end{array}$ & $\begin{array}{l}6870 \pm 999 \\
16 \% \\
20 \%\end{array}$ & $\begin{array}{l}\mathrm{kg} / \mathrm{ha} \\
\frac{1}{17} \%\end{array}$ \\
\hline $\begin{array}{l}\text { Upland meadow } \\
24 \mathrm{~h} \\
12 \mathrm{~h}\end{array}$ & $\begin{array}{l}550 \pm 100 \\
43 \% \\
42 \%\end{array}$ & $\frac{\mathrm{kg} / \mathrm{ha}}{\overline{78} \%}$ & $\begin{array}{l}539 \pm 190 \\
49 \% \\
50 \%\end{array}$ & $\begin{array}{l}\mathbf{k g} / \mathbf{h a} \\
\frac{37}{37} \%\end{array}$ \\
\hline $\begin{array}{l}\text { Lowland meadow } \\
24 \mathrm{~h} \\
12 \mathrm{~h}\end{array}$ & $\begin{array}{l}3705 \pm 797 \\
28 \% \\
24 \%\end{array}$ & $\begin{array}{l}\mathrm{kg} / \mathrm{ha} \\
\frac{-}{2} \%\end{array}$ & $\begin{array}{c}2516 \pm 296 \\
31 \% \\
24 \%\end{array}$ & $\begin{array}{l}\mathrm{kg} / \mathrm{ha} \\
31 \%\end{array}$ \\
\hline $\begin{array}{l}\text { Forest } \\
24 \mathrm{~h} \\
12 \mathrm{~h}\end{array}$ & $\begin{array}{c}1 \% \\
<1 \%\end{array}$ & $\overline{3 \%}$ & $\begin{array}{l}4 \% \\
6 \%\end{array}$ & $\overline{15 \%}$ \\
\hline
\end{tabular}

'Grazing times for $24 \mathrm{~h}$ and $12 \mathrm{~h}(0600-1800 \mathrm{~h})$ period.

Most foraging time was spent on grassy upland meadows and least in poplar forests. Although information is limited, bison appeared to use the same proportions of habitats while grazing during daylight and darkness.

\section{Foraging Rates}

The maximum consumption rate of bison feeding on herbaceous vegetation was $67.5 \mathrm{~g} / \mathrm{min}$. Although insufficient data were obtained during autumn to fit a separate relationship and test significance, there was no obvious difference between summer and autumn (Fig. 2). When pasture biomass was $779 \mathrm{~kg} / \mathrm{ha}$, consumption rates fell to one half of this maximum.

This asymptotic relationship resulted from the interactions of bite size and bite rate. Bite sizes increased logarithmically with forage biomass to almost $1.2 \mathrm{~g} /$ bite on pastures supporting approximately $3,000 \mathrm{~kg} / \mathrm{ha}$ (Fig. 3). Cropping bite rates declined moderately from an observed maximum of 65 bites/min to 46 bites/min over this range of bite sizes (Fig. 4). 

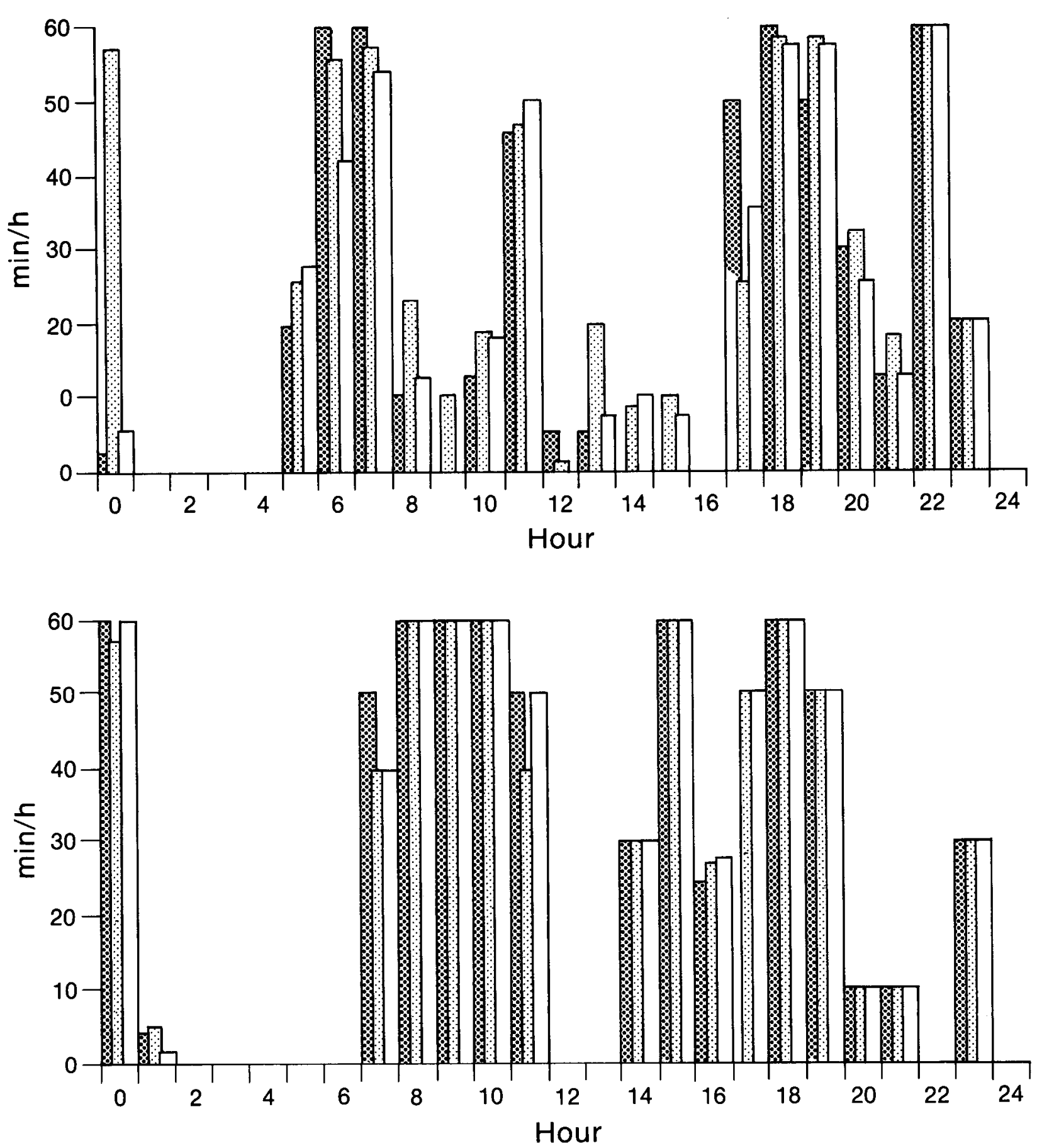

Fig. 1. Foraging times (min/h) of bison during 24 h on $20 \mathrm{July}$ (above) and 20 October (below). Dark bars-subadult males; medium bars-adult cows; light bars-yearlings.

\section{Discussion}

\section{Foraging Efficiency}

Maximum foraging rates of ruminants scale to body size (Clutton-Brock and Harvey 1983, Wickstrom et al. 1984). Compared with $68 \mathrm{~g} / \mathrm{min}$ for bison, maximum rates determined on summer pastures in the same study area were $18 \mathrm{~g} / \mathrm{min}$ for wapiti (Hudson and Nietfeld 1985) and $23 \mathrm{~g} / \mathrm{min}$ for moose (Renecker and Hudson 1986). Estimates of over $60 \mathrm{~g} / \mathrm{min}$ have been obtained for beef cattle in other parts of central Alberta (Arthur 1984). Therefore, on the basis of body size, maximum feeding rates observed for bison are consistent with expectations.

Larger herbivores are also expected to require higher forage biomass to achieve these maxima (Wickstrom et al. 1984). However, interspecific patterns are not all that clear even with due consideration for habitat structure and forage preferences. In this study, bison foraged more efficiently on sparse pastures than might be expected. In spite of their considerably larger size, the critical biomass $\left(B^{50}\right)$ of $779 \mathrm{~kg}$ / ha for bison fell within the range of 542 $\mathrm{kg} / \mathrm{ha}$ (Wickstrom et al. 1984) and $1,000 \mathrm{~kg} / \mathrm{ha}$ (Hudson and Nietfeld 1985) reported for wapiti in grassland habitats.

The high feeding rate of bison is achieved by large bite sizes and rapid bite rates. Bite sizes on short uniform swards are determined largely by the width of the incisor bar $(6.5 \mathrm{~cm}$ measured in a single adult bison cow). In our study, bison seldom prehended even long 


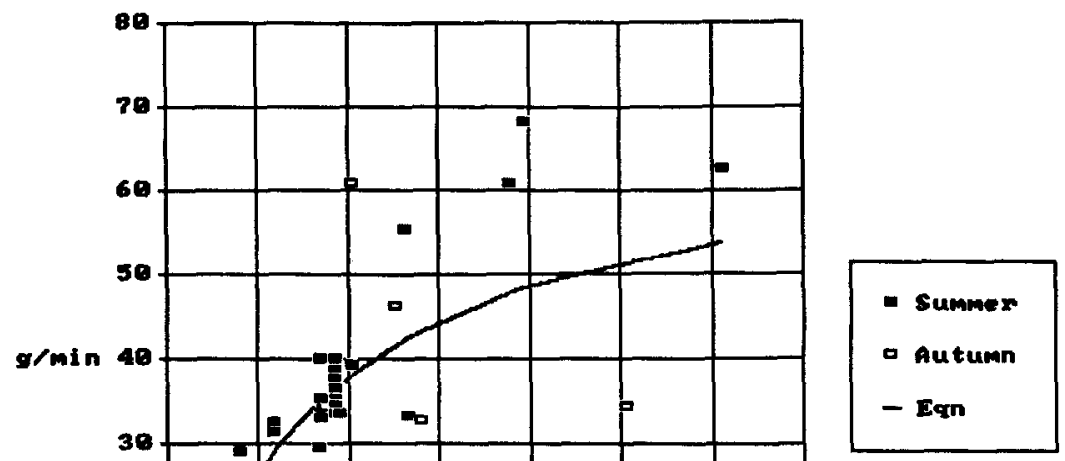

Fig. 2. Intake rates of bison in relation to forage biomass during summer (closed symbols) and autumn $\left(\right.$ open symbols): $Y=(67.5 X) /(779+X), \mathrm{r}^{2}=0.55$.

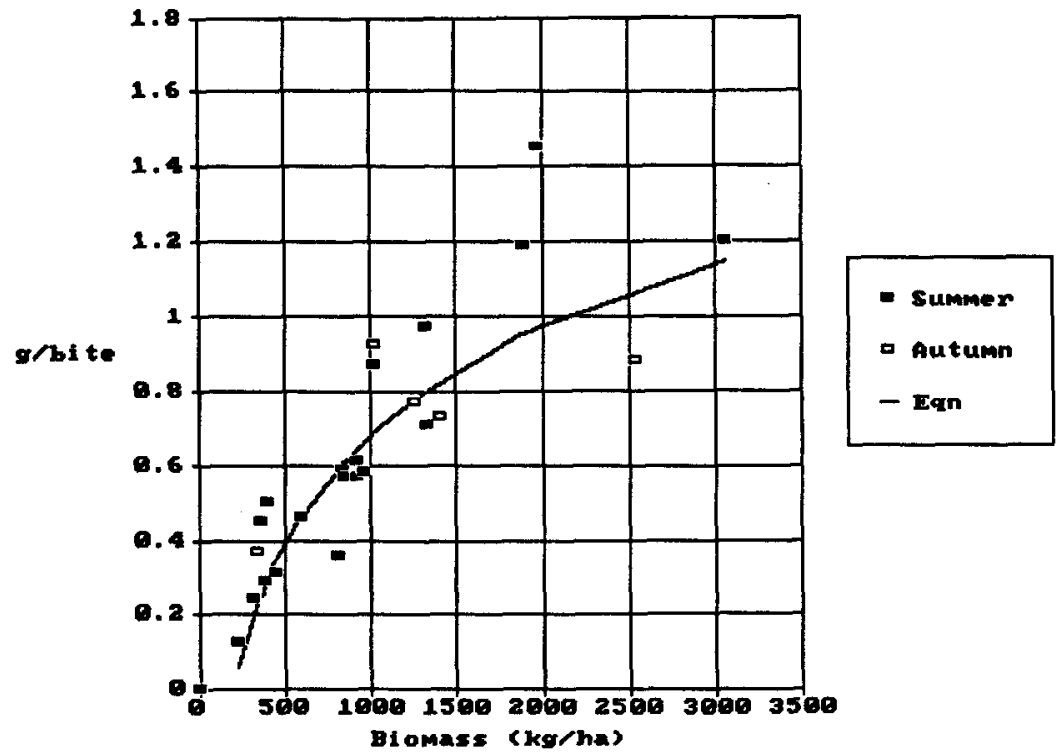

Fig. 3. Bite sizes of bison in relation to forage biomass during summer (closed symbols) and autumn (open symbols): $\mathrm{Y}=2.22+0.42$ in $\mathrm{X}, \mathrm{r}^{2}=0.74$.

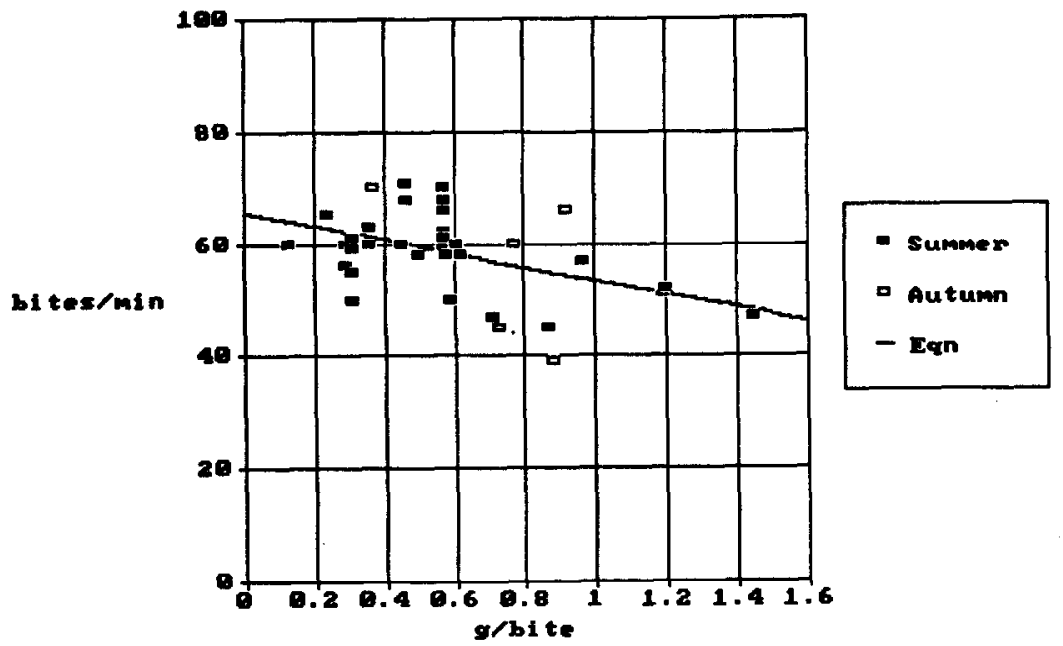

Fig. 4. Cropping bite rates of bison in relation to bite size during summer (closed symbols) and autumn (open symbols): $\mathrm{Y}=65.7-12.3 \mathrm{X}, \mathrm{r}^{2}=0.21$. 
forage with their tongues in a horizontal plane. The curvilinear relationship of bite size to forage biomass presumably arises because of the vertical distribution of pasture biomass as well as upper limits of mouth volume.

The inverse relationship between biting rates and bite sizes has several explanations (Wickstrom et al. 1984, Hudson and Nietfeld 1985). An obvious explanation is that grazing animals attempt to compensate for smaller bites by feeding faster. However, the decline in bite rates may be imposed by increased handling time required to wet, masticate, and swallow larger bites. Compared with wapiti, cropping bite rates of bison were high at an equivalent forage biomass and declined less sharply with increasing bite sizes. This may mean that bison spend less time selecting and/or less time handling forage. Under the conditions of this study, the superior handling efficiency of bison probably is most important because these pastures offered little opportunity for selection. Although differences in this relationship between summer and autumn forages might be expected, contrasts in fibrousness were not great since most pastures grazed in the autumn showed some regrowth.

Because of the weak relationship between bite rate and and bite size, intake rates of bison on grasslands are determined primarily by bite size, which is strongly influenced by forage biomass. Based on their studies on reindeer and comparisons of published information, Trudell and White (1981) pointed to considerable variation in the relative importance of these two parameters. While the bison represents one extreme, reindeer represent the other in which bite sizes vary little with forage biomass. Trudell and White's (1981) argument that high biting rates of reindeer indicate selectivity is not inconsistent with our seemingly contradictory explanation for bison. At low forage biomass, reindeer may spend more time searching for acceptable forage items; therefore, biting rates increase with forage biomass as long as bite size does not inordinately increase handling times The main feature of selective feeding appears to be constancy of bite sizes.

High foraging efficiency permitted bison to meet their forage requirements without prolonged foraging. Grazing times observed in this study $(8.7-10.7 \mathrm{~h} / \mathrm{d})$ were no greater than those of wapiti (8-13 h/d) on the same pastures (Gates and Hudson 1983). Average foraging rates (calculated from habitat-specific forage biomass and proportional habitat use) declined slightly from summer (43 $\mathrm{g} / \mathrm{min}$ ) to autumn $(39 \mathrm{~g} / \mathrm{min})$. However, extending foraging times by $2 \mathrm{~h}$ permitted bison to actually increase daily dry matter intakes. Potential daily intakes calculated in this way exceed $5 \%$ of body weight. Actual intakes probably were at least $50 \%$ lower because feeding rates applied only to uninterrupted feeding at a single station.

\section{Trophic Strategies}

By conventional criteria, the digestive efficency of bison is high, particularly on fibrous forage (Peden et al. 1974, Richmond et al. 1977, Hawley et al. 1981). Nevertheless, superior digestion coefficients usually are not reflected in better feed conversion efficiency ( $\mathrm{kg}$ gain/ $\mathbf{k g}$ forage) in comparisons with cattle that digest coarse forages less well (Richmond et al. 1977). One reason for these patterns may be that that proportion of acetate among volatile fatty acids increases as digestion proceeds, providing a deficit of glucogenic precursors (Van Soest 1982). This should have minor effects on the efficiency of utilization of metabolizable energy for maintenance, but exert more important reductions in the efficiency of growth. Another penalty of prolonged retention of digesta is reduced intake. Although low dry matter intakes are offset by higher digestibilities, daily intakes of digested organic matter in bison are low compared with many other large grazing ruminants (Foose 1982).

This pattern of digestive adaptation should convey a competitive advantage in circumstances where forage is in limited supply and there are few opportunities to forage selectively. It is a conservative strategy of using limited resources rather completely. To complement this digestive strategy, one would expect bison to forage efficiently on grass swards even at low biomass densities. This study confirms this expectation.

Bison bison like its immediate ancestor (Bison occidentalis) is a grassland specialist that seemed to rapidly fill a niche left vacant by megafaunal extinctions at the Pleistocene-Holocene boundary (McDonald 1981). Modern bison evolved as recently as 5,000 years BP when forests and savannas were replaced by grasslands. They dominated this environment as evidenced by the abundance of fossilized bones and dense populations which existed at the time of European exploration and settlement. High foraging efficiency would have permitted the attainment of such high population densities and indeed this adaptation could have been honed by prolonged existence at high densities.

\section{Literature Cited}

Arthur, R.L. 1984. Plant community and forage preferences of cattle on native aspen parkland range. MSc. thesis, University of Alberta, Edmonton.

Christopherson, R.J., R.J. Hudson, and R.J. Richmond. 1978. Comparative winter bioenergetics of American bison, yak, Scottish highland and Hereford calves. Acta Theriol. 23:49-54.

Christopherson, R.J., R.J. Hudeon, and M.K. Christopherwew. 1979. Seasonal energy expenditures and thermoregulatory responses of bison and cattle. Can. J. Anim. Sci. 59:611-617.

Clutton-Brock, T.H., and P.H. Harvey. 1983. The functional significance of variation in body size among mammals, p. 632-663. In. J.F. Eisenberg and D.G. Kleiman (eds.), Advances in the study of mammalian behavior. Spec. Pub. 7, Amer. Soc. Mammalogists.

Dixon, W.J. (ed.) 1981. BMDP statistical software. Univ. of California Press, Berkeley.

Foose, T.J. 1982. Trophic strategies of ruminant verus nonruminant ungulates. Ph.D. Thesis, Univ. of Chicago, Chicago.

Gates, C.C., and R.J. Hudson. 1983. Foraging behavior of wapiti in a boreal forest enclosure. Naturaliste Can. (Rev. Ecol. Sys.) 110:197-206.

Hawley, A.W.L., D.G. Peden, and W.R. Stricklin. 1981. Bison and Hereford steer digestion of sedge hay. Can. J. Anim. Sci. 61:165-174.

Hudson, R.J., and R.J. Christopherson. 1985. Maintenance metabolism, p. 121-142. In: R.J. Hudson and R.G. White (eds.), Bioenergetics of wild herbivores. CRC Press, Boca Raton.

Hudson, R.J., and M.T. Nietfeld. 1985. Effect of forage depletion on the feeding rate of wapiti. J. Range Manage. 38:80-82.

MeDonald, J.N. 1981. North American bison: Their classification and evolution. Univ. of California Press, Berkeley.

Moodie, D.W., and A. Kay. 1976. Bison migrations in the Canadian Plains. Plains Anthropol. 21:45-52.

Morgan, R.G. 1980. Bison movement patterns on the Canadian Plains. Plains Anthropol. 25:142-160.

Peden, D.G., G.M. Van Dyne, R.W. Rice, and R.M. Hanem. 1974. The trophic ecology of Bison bison L. on shortgrass plains. J. Appl Ecol. 11:489-498.

Renecker, L.A., and R.J. Hudson. 1986. Seasonal foraging rates of moose in apen boreal habitats. J. Wildl. Manage. 50:143-147.

Reynolds, H.W., R.D. Glaholt, and A.W.L. Hawley. 1982. Bison (Bison bison) p. 972-1007. In: J.A. Chapman and G.A. Feldhamer (eds.), Wild mammals of North America: Biology, management and economics. John Hopkins Univ. Press, Baltimore.

Richmond, R.J., R.J. Hudson, and R.J. Christophereon. 1977. Comparison of forage intake and digestibility by American bison, yak and cattle. Acta Theriol. 22:225-230.

Roe, F.G. 1970. The North American buffalo: a critical study of the species in its wild state. Univ. of Toronto Press, Toronto.

Rowe, J.S. 1972. Forest regions of Canada. Dept. Environ. Can. Forest Serv. Pub. No. 1300.

Trudell, J., and R.G. White. 1981. The effect of forage structure and availability on food intake, biting rate, bite size and daily eating time of reindeer. J. Appl. Ecol. 18:63-81.

Van Soest, P.J. 1982. Nutritional ecology of the ruminant. O \& Books, Corvallis.

Wickstrom, M.L., C.T. Robbins, T.A. Hanley, D.E. Spalinzer, and S.M. Parish. 1984. Food intake and foraging energetics of elk and mule deer. J. Wildl. Manage. 48:1285-1301. 